\title{
PEMANFAATAN TEKNOLOGI INFORMASI DAN KOMUNIKASI DALAM METODE BERCERITA
}

\section{Utilization of Information and Communication Technology in Story Telling Method}

\author{
Mohammad Siddiq dan Hartini Salama \\ Universitas Ibnu Chaldun, Jakarta
}

JI. Pemuda I Kav. 97, Rawamangun, Jakarta Timur, DKI Jakarta 13220, Indonesia

\author{
Ahmad Juma Khatib \\ Universitas Gunadarma \\ Jl. Margonda Raya No.100, Pondok Cina, Kecamatan Beji, \\ Kota Depok, Jawa Barat 16424, Indonesia \\ 2.moh.siddiq@gmail.com
}

\author{
Diterima: \\ 12 Desember 2018, \\ Direvisi: \\ 16 Maret 2019, \\ Disetujui: \\ 10 November 2020
}

\begin{abstract}
ABSTRAK: Cerita atau dongeng semestinya berada pada posisi pertama dalam mendidik etika kepada anak. Mereka cenderung menyukai dan menikmatinya, baik dari segi ide, imajinasi, maupun peristiwa-peristiwanya. Jika hal ini dapat dilakukan dengan baik, cerita akan menjadi bagian dari seni yang disukai anak-anak, bahkan orang dewasa. Dalam hal pendidikan anak, khususnya tentang bercerita, penting bagi orang tua dan guru untuk memilih cerita dan cara penyampaian kepada anak-anak secara tepat. Perkembangan teknologi masa kini tentu dapat mendukung cara penyampaian cerita agar lebih menarik lagi bagi anak. Penelitian yang menggunakan pendekatan paradigma kualitatif dengan metode telaah pustaka (literature study) ini bertujuan untuk memberikan pemahaman tentang bagaimana memilih cerita, dan bagaimana cara menyampaikannya pada anak dengan memanfaatkan Teknologi Informasi dan Komunikasi (TIK). Berdasarkan kajian ini, dapat diketahui bahwa pemanfaatan TIK dalam mendukung penyampaian cerita sekurangnya memiliki dua aspek, yaitu efek visual dan efek audio. Oleh karena itu, pencerita hendaknya dapat mempelajari bagaimana merancang dan memanfaatkan TIK tersebut secara optimal untuk menyampaikan cerita.
\end{abstract}

Kata Kunci: Teknologi Informasi dan Komunikasi (TIK), metode bercerita, pendidikan anak.

\begin{abstract}
Stories or tales should be in the first position in educating ethics to children. They tend to like and enjoy it, in terms of the ideas, imaginations, as well as events. If this can be done well, story will be a part of the art that the children, and even the adults, love. In child education, especially in storytelling, it is important for parents and teachers to choose stories and ways of delivering them to the children properly. The development of today's technology can certainly support the ways of storytelling to be more interesting to children. The objective of this research is to get understanding on how to choose stories and on how to deliver them to the children by using Information and Communication Technology (ICT). This
\end{abstract}


research applies qualitative paradigm approach with the method of literature study. Based on this study, the use of ICT in storytelling has at least two aspects, namely visual and audio effects. Therefore, the storytellers should be able to learn how to design and use ICT to deliver stories optimally.

Keywords: Information and Communication Technology (ICT), storytelling method, children education

\section{PENDAHULUAN}

Masa kanak-kanak merupakan bagian dari masa perkembangan yang mempunyai banyak sisi yang membutuhkan pengkajian, uji coba, dan penggalian yang mendasar sehingga diperoleh hasil yang dapat menjadi petunjuk bagi para guru dan orang tua. Dari sisi kekanak-kanakannya, anak-anak akan selalu membutuhkan pengajaran etika, apa yang baik dan buruk bagi mereka. Oleh karena itu, guru dan orang tua dituntut untuk dapat menetapkan ukuran-ukuran kebaikan itu dan menggali hal-hal khusus tentang budi pekerti, serta berupaya memperkayanya agar selalu lebih menarik dan menyenangkan mereka.

Cerita atau dongeng semestinya berada pada posisi pertama dalam mendidik etika kepada anak. Mereka cenderung menyukai dan menikmatinya, baik dari segi ide, imajinasi, maupun peristiwa-peristiwanya. Jika hal ini dapat dilakukan dengan baik, cerita akan menjadi bagian dari seni yang disukai anak-anak, bahkan orang dewasa. Sungguh memprihatinkan ketika kita kerap kali menjumpai anak-anak masa kini yang jauh dari budi pekerti yang baik, jauh dari kisah-kisah inspiratif yang akan mendidik rasa, imajinasi, akhlak, serta memberikan pengetahuan dan mengembangkan karakter luhur mereka.

Fase awal belajar adalah masa yang dilalui sebelum anak memasuki fase belajar lanjutan, yaitu selepas mereka dari usia balita hingga menjelang akhir masa kanak-kanak. Fase ini mencakup masa pengasuhan, pendidikan di taman kanak-kanak, sekolah dasar, sampai anak memasuki sekolah lanjutan pertama. Masa ini adalah masa menjelang usia dewasa.
Anak mulai dapat mendengarkan cerita sejak ia dapat memahami apa yang terjadi di sekelilingnya, dan mampu mengingat apa yang disampaikan orang kepadanya. Hal itu biasanya terjadi pada akhir usia tiga tahun. Pada usia ini, anak mampu mendengarkan cerita pendek yang diceritakan kepadanya dengan baik dan cermat. la bahkan akan meminta cerita tambahan. Kita ingat, ketika kecil, seringkali pada malam hari sebelum tidur atau pada waktu-waktu santai, mendengarkan berbagai cerita dari orang tua kita, seperti cerita tentang orang yang cerdik, cerita hantu, putri raja, hewan-hewan di hutan, dan lain sebagainya. Banyak dari kita yang mengharapkan agar waktu cerita menjadi panjang dan orang tua kita terus bercerita. Kita juga ingat bahwa kita tidak pernah bosan dengan cerita yang diulang-ulang dan sepertinya tidak pernah basi.

Dalam cerita terdapat ide, tujuan, imajinasi, bahasa, dan gaya bahasa. Unsurunsur tersebut berpengaruh dalam pembentukan pribadi anak. Dari sinilah tumbuh kepentingan untuk mengambil manfaat dari cerita di sekolah maupun di rumah. Penting bagi orang tua dan guru untuk memilih cerita dan cara menyampaikannya kepada anak secara tepat. Oleh karena itu, penetapan pelajaran bercerita pada masa awal sekolah dasar adalah bagian terpenting dari pendidikan. Pelajaran bahasa mengambil peran pada bagian ini melalui cerita sastra yang baik bagi anak-anak. Melalui penyimakan cerita yang disajikan, anak-anak akan mengembangkan keterampilan menyimak mereka sekaligus menyerap nilainilai dalam cerita tersebut. 
Perkembangan teknologi masa kini tentulah dapat mendukung bagaimana cerita tersebut dapat disampaikan agar lebih menarik lagi bagi anak. Sebagai contoh, penelitian yang dilakukan oleh Ernayanti, dkk (2017) mengenai terdapatnya hasil yang berbeda dalam kemampuan menyimak anak yang diberikan pembelajaran dengan metode bercerita bermediakan audio visual dengan anak yang diberikan pembelajaran dengan metode konvensional. Penelitian lainnya yang dilakukan oleh Daroah (2013) juga menunjukkan kemampuan bahasa yang dicapai anak didik lebih meningkat dibandingkan dengan sebelumnya saat menggunakan metode bercerita dengan menggunakan media audio visual. Hal tersebut kemudian mendorong peneliti untuk mengkaji lebih dalam lagi mengenai bagaimanakah sebenarnya implementasi dan pemanfaatan Teknologi Informasi dan Komunikasi (TIK) dalam metode bercerita.

Berdasarkan uraian di atas, dapat dirumuskan permasalahan yang menjadi fokus dalam penelitian ini. Permasalahan tersebut adalah bagaimanakah pemanfaatan Teknologi Informasi dan Komunikasi (TIK) dalam metode bercerita. Tujuan penelitian ini adalah untuk memperoleh pemahaman mengenai pemanfaatan Teknologi Informasi dan Komunikasi (TIK) dalam metode bercerita.

\section{METODA}

Penelitian ini menggunakan pendekatatan paradigma kualitatif dengan metoda telaah pustaka (literature study) dengan tujuan untuk memahami bagaimana memilih cerita, bagaimana cara menyampaikannya pada anak, dan memanfaatkan TIK dalam menyampaikan sebuah cerita. Dalam hal ini, penelitian tidak didasarkan pada suatu hipotesis tertentu, melainkan atas beberapa persoalan dasar yang selanjutnya digunakan dalam rangka menjawab tujuan penelitian yang kemudian dianalisis dan disajikan secara deskriptif (Siddiq\& Hamidi, 2015)

\section{Mengarang Cerita}

Seni adalah sumber dari rasa keindahan dan bagian dari pendidikan. Salah satu bagian seni adalah seni sastra, termasuk cerita, di mana di dalamnya terdapat kenikmatan dan kesenangan bagi pengarang yang telah menyusun dan mengarangnya, pendongeng yang menyampaikannya, dan penyimak yang menyimaknya. Seni memberi pengaruh pada jiwa orang dewasa maupun anak-anak, karena ia dapat mengasah akal dan rasa. Seni yang disajikan untuk anak-anak haruslah berbeda, baik kualitas, kuantitas, gaya bahasa, maupun metode penyampaiannya. Cerita merupakan salah satu bentuk sastra yang memiliki keindahan dan kenikmatan tersendiri. Akan menyenangkan bagi anakanak maupun orang dewasa, jika pegarang, pendongeng dan penyimaknya sama-sama baik. Cerita adalah salah satu bentuk sastra yang bisa dibaca atau hanya didengar oleh orang yang tidak bisa membaca. Dalam cerita, ada beberapa pokok yang masing-masing akan saling berkaitan, yaitu pengarang, karangan, pencerita, penceritaan, penyimak dan penyimakan.

Karangan adalah pembuatan cerita dan penyusunannya. Pengarang adalah penulis cerita, karena ia yang mengarang cerita, di mana idenya berdasarkan imajinasi sendiri maupun berasal dari tema yang sengaja dipilihnya. Penceritaan adalah penyampaian cerita kepada pendengar atau membacakannya bagi mereka. Dalam proses penceritaan ini, dibutuhkan adanya hal-hal yang mencakup posisi duduk pencerita, bahasa, suara, gerakan-gerakan, peragaan peristiwa-peristiwanya, dan aura yang melingkupi antara dirinya dan penyimak agar penceritaan menjadi baik. Pencerita adalah orang yang menyampaikan cerita kepada penyimak. Penyimakan adalah kegiatan menyimak cerita, mencakup kondisi pendengar, tingkat perhatian, tingkat keberpengaruhan cerita terhadap jiwa mereka, dan lain sebagainya. Penyimak adalah individu atau banyak orang yang mendengarkan cerita (Majid, 2001: 8-9). Karangan, pengarang, penceritaan, pencerita, penyimakan, dan penyimak adalah komponen pokok yang harus diperhatikan sehingga 
sebuah cerita layak disebut bagian dari sastra yang hidup dan abadi.

Menurut Majid (2001: 10), mengarang cerita mencakup tiga unsur pokok. Pertama, ide yang terkandung dalam cerita, sisi kejiwaan, kesesuaian dengan pembaca atau pendengar. Kedua, susunan ide yang teratur. Ketiga, bahasa dan gaya bahasa yang dibentuk oleh ide.

\section{Ide dan Susunan Ide}

Ide dalam mengarang cerita adalah suatu bakat alami yang terlahir dari seseorang. Sebagian orang mungkin dapat memperoleh dan membuatnya dengan latihan yang sangat keras jika bakat itu tidak ada. Namun hal tersebut akan ditempuhnya dengan lebih sulit jika dibandingkan dengan seseorang yang terlahir dengan bakat, seperti sulitnya seseorang untuk langsung bermusik atau bersyair.

Rasa senang saja tidak cukup bagi seseorang untuk mewujudkan sebuah seni, namun harus ada bimbingan, pengembangan, dan pengarahan. Hal tersebut akan menghasilkan kecenderungan dan rasa kemanusiaan yang berbeda-beda. Para ahli pendidikan sangat memperhatikan ide dari belajar dengan bermacam-macam cerita ini, untuk mengetahui sejauh mana pengaruhnya dalam pertumbuhan akal dan emosi anak melalui tema yang beragam.

Tema adalah ide pokok sebuah cerita, yang diyakini dan dijadikan sumber cerita. Tema merupakan suatu gagasan pokok atau ide pikiran tentang suatu hal, salah satunya adalah tentang sebuah cerita. Jadi, jika diandaikan seperti sebuah rumah, tema adalah fondasinya. Tema juga merupakan suatu hal yang paling utama dilihat oleh para pembaca sebuah cerita. Jika menarik, tema ini akan memberikan nilai lebih pada cerita tersebut.

Ide pokok menjadi unsur paling penting dalam penyusunan sebuah cerita karena ini menjadi pegangan pengarang dalam menentukan elemen struktural lain, seperti plot, tokoh, dan latar. Sebenarnya, semua unsur dalam cerita saling berkaitan dan tidak dapat dianggap sepele. Ketika unsur dalam cerita tersebut dapat dipenuhi dengan baik, dapat dikatakan bahwa sebuah cerita tersebut baik untuk dibaca atau diikuti alur ceritanya. Keraf (2005:145) dalam Gultom dan Suryani (2017) menyatakan bahwa ide pokok atau tema, alur, cerita, tokoh, dan pesan merupakan unsur-unsur yang membangun karangan selain unsur lainnya, yakni, perbuatan, penokohan, latar, dan sudut pandang.

Sebuah cerita dikarang oleh seorang pengarang dengan unsur penyusun ceritanya. Pembaca ataupun para pemirsa dari sebuah cerita akan mudah mengenali ide pokok sebuah cerita jika pengarangnya pandai dalam menentukan alur serta memahamkan para tokohnya dengan alur cerita tersebut. Ide pokoklah yang memiliki peran sebagai titik awal yang menuntun pengarang dalam menciptakan dan membentuk plot atau membawa tokoh menjadi serasa hidup. Ada pun fungsi terpenting tema dalam sebuah cerita adalah menjadi elemen penyatu terakhir keseluruhan cerita. Ketika ide pokok tersebut sulit ditemukan pada sebuah cerita, dapat dikatakan bahwa cerita tersebut kurang baik untuk disebarkan.

\section{Bahasa dan Gaya Bahasa}

Gaya bahasa adalah pemanfaatan atas kekayaan bahasa seseorang dalam bertutur atau menulis, pemakaian ragam tertentu untuk memperoleh efek-efek tertentu, keseluruhan ciri-ciri bahasa sekelompok penulis sastra (Kridalaksana, 2001:63). Henry Guntur Tarigan (1982:5) mengatakan bahwa gaya bahasa merupakan bentuk retorik, yaitu penggunaan kata-kata dalam berbicara dan menulis untuk meyakinkan atau mempengaruhi penyimak dan pembaca. Gaya bahasa menurut Gorys Keraf adalah cara mengungkapkan pikiran melalui bahasa secara khas yang memperlihatkan jiwa dan kepribadian penulis (pemakaian bahasa). Dale dalam Henry Guntur Tarigan (1982:5) mengatakan bahwa gaya bahasa indah yang dipergunakan untuk meningkatkan efek dengan jalan memperkenalkan serta memperbandingkan suatu benda atau hal lain yang lebih umum (gaya bahasa tertentu dapat mengubah serta menimbulkan konotasi tertentu). Menurut Gorys Keraf, gaya bahasa 
terbagi menjadi dua jenis, yaitu dari segi non bahasa dan bahasa. Berdasarkan segi non bahasa, gaya bahasa didasarkan pada tujuh bagian berikut ini, yaitu: (1) pengarang; (2) medium; (3) subjek; (4) tempat; (5) masa; (6) hadirin; dan (7) tujuan. Sedangkan dari segi bahasa, gaya bahasa dapat dibedakan berdasarkan titik tolak unsur bahasa yang dipergunakan. Gaya bahasa berdasarkan segi bahasa ini terdiri dari: (1) gaya bahasa berdasarkan pilihan kata; (2) gaya bahasa berdasarkan nada; dan (3) gaya bahasa berdasarkan struktur kalimat.

Menurut Trisanto (2013), pentingnya gaya bahasa untuk diperhatikan dalam sebuah karangan adalah dengan pertimbangan bahwa gaya bahasa yang digunakan pengarang akan menentukan kualitas dari karya tulis yang diciptakannya. Hal ini karena beberapa hal berikut ini. Pertama, bahasa adalah unsur terpenting dalam karya sastra. Kedua, gaya bahasa merupakan ciri khas seorang pengarang yang membedakannya dengan pengarang lainnya. Ketiga, keberagaman pengarang dalam menggunakan gaya bahasa mampu mengemban nilai estetika, menimbulkan tanggapan tertentu oleh pembaca, serta mendukung makna cerita pada karya yang diciptakannya. Keempat, gaya bahasa merupakan satu di antara materi yang diajarkan pada mata pelajaran Bahasa Indonesia di sekolah. Pertimbangan tersebut dapat digunakan para guru dalam memilih cerita yang akan digunakan dalam pembelajaran.

\section{Memahami Teknologi Informasi dan Komunikasi}

Teknologi Informasi adalah suatu teknologi yang digunakan untuk mengolah data, termasuk memproses, mendapatkan, menyusun, menyimpan, memanipulasi data dalam berbagai cara untuk menghasilkan informasi yang berkualitas, yaitu informasi yang relevan, akurat, dan tepat waktu yang digunakan untuk keperluan pribadi, bisnis, dan pemerintahan yang merupakan informasi yang strategis untuk pengambilan keputusan. Teknologi Informasi dan Komunikasi (TIK) adalah payung besar terminologi yang mencakup seluruh peralatan teknis untuk memproses dan menyampaikan informasi. TIK mencakup dua aspek yaitu teknologi informasi dan teknologi komunikasi. Teknologi informasi meliputi segala hal yang berkaitan dengan proses, penggunaan sebagai alat bantu, manipulasi, dan pengelolaan informasi.

Sedangkan teknologi komunikasi adalah segala sesuatu yang berkaitan dengan penggunaan alat bantu untuk memproses dan mentransfer data dari perangkat yang satu ke lainnya. Oleh karena itu, teknologi informasi dan teknologi komunikasi adalah dua buah konsep yang tidak terpisahkan. Jadi, Teknologi Informasi dan Komunikasi mengandung pengertian luas yaitu segala kegiatan yang terkait dengan pemrosesan, manipulasi, pengelolaan, pemindahan informasi antarmedia.

Istilah TIK muncul setelah adanya perpaduan antara teknologi komputer (baik perangkat keras maupun perangkat lunak) dengan teknologi komunikasi pada pertengahan abad ke-20. Perpaduan kedua teknologi tersebut berkembang pesat melampaui bidang teknologi lainnya. Hingga awal abad ke-21, TIK masih terus mengalami berbagai perubahan dan belum terlihat titik jenuhnya. Teknologi informasi dan komunikasi ini menggunakan seperangkat komputer untuk mengolah data, sistem jaringan untuk menghubungkan satu komputer dengan komputer yang lainnya sesuai dengan kebutuhan, dan teknologi telekomunikasi digunakan agar data dapat disebar dan diakses secara global.

Teknologi informasi bagi dunia pendidikan seharusnya berarti tersedianya saluran atau sarana yang dapat dipakai untuk menyiarkan program pendidikan. Pemanfaatan teknologi informasi dalam bidang pendidikan sudah merupakan kelaziman. Hal ini untuk membantu menyediakan komputer dan jaringan yang menghubungkan rumah murid dengan ruang kelas, guru, dan administrator sekolah. Semuanya dihubungkan ke internet, dan para guru dilatih menggunakan komputer pribadi.

Peran yang dapat diberikan oleh aplikasi teknologi informasi ini adalah menyediakan 
informasi untuk kehidupan pribadi seperti informasi tentang kesehatan, hobi, rekreasi, rohani, maupun profesi seperti sains, teknologi, perdagangan, berita bisnis, dan asosiasi profesi. Selain itu, aplikasi teknologi informasi ini juga sebagai sarana kerjasama antara pribadi atau kelompok yang satu dengan pribadi atau kelompok yang lainnya tanpa mengenal batas jarak dan waktu, negara, ras, kelas ekonomi, ideologi atau faktor lainnya yang dapat menghambat bertukar pikiran. Perkembangan teknologi informasi memacu suatu cara baru dalam kehidupan, dari awal dimulainya kehidupan sampai dengan berakhirnya kehidupan. Kehidupan seperti ini dikenal dengan istilah e-life, artinya kehidupan ini sudah dipengaruhi oleh berbagai kebutuhan secara elektronik.

\section{TIK sebagai Media Pembelajaran}

Perkembangan TIK telah memberikan pengaruh terhadap dunia pendidikan khususnya dalam proses pembelajaran. Dengan berkembangnya penggunaan $\mathrm{TIK}$, ada lima pergeseran dalam proses pembelajaran yaitu: (1) dari pelatihan ke penampilan; (2) dari ruang kelas ke "di mana saja dan kapan saja"; (3) dari kertas ke "online" atau saluran; (4) fasilitas fisik ke fasilitas jaringan kerja; dan (5) dari waktu siklus ke waktu nyata. Komunikasi sebagai media pendidikan dilakukan dengan menggunakan media-media komunikasi seperti telepon, komputer, internet, e-mail, dan sebagainya.

Interaksi antara guru dan siswa tidak hanya dilakukan melalui hubungan tatap muka, tetapi juga dilakukan dengan menggunakan berbagai media tersebut. Guru dapat memberikan layanan tanpa harus berhadapan langsung dengan siswa. Demikian pula siswa dapat memperoleh informasi dalam lingkup yang luas dari berbagai sumber melalui cyber space atau ruang maya dengan menggunakan komputer atau internet. Teknologi informasi saat ini telah berkembang sangat pesat. Di sektor swasta, kantor-kantor pemerintah, BUMN, dan sekolah-sekolah di kota maupun daerah, banyak yang memiliki jaringan internet. Sekolah yang telah memanfaatkan TIK dalam kegiatan belajar mengajarnya akan sangat berbeda dengan sekolah yang belum memanfaatkannya.

Fakta di atas membuktikan bahwa perkembangan teknologi informasi yang begitu cepat menuntut peningkatan kualitas pendidikan sumber daya tenaga pendidik. Dunia pendidikan dituntut memahami teknologi informasi dan komunikasi. Kendala pendidikan kita adalah akses atau ketersediaan pendidikan bagi rakyat yang masih sangat rendah (Wibowo, 2006). Keterbatasan ini juga termasuk keterbatasan perangkat TIK.

TIK telah mengubah peran guru dan siswa dalam pembelajaran. Peran guru telah berubah dari: (1) sebagai penyampai pengetahuan, sumber utama informasi, ahli materi, dan sumber segala jawaban menjadi sebagai fasilitator pembelajaran, pelatih, kolaborator, navigator pengetahuan, dan mitra belajar; serta (2) dari mengendalikan dan mengarahkan semua aspek pembelajaran menjadi lebih banyak memberikan banyak alternatif dan tanggung jawab kepada setiap siswa dalam proses pembelajaran. Sementara itu, peran siswa dalam pembelajaran telah mengalami perubahan yaitu: (1) dari penerima informasi yang pasif menjadi partisipan aktif dalam proses pembelajaran; (2) dari mengungkapkan kembali pengetahuan menjadi menghasilkan dan berbagai pengetahuan; (3) dari pembelajaran sebagai aktivitas individual (soliter) menjadi pembelajaran berkolaborasi dengan siswa lain. Dalam pandangan Haryoko (2009), apabila dibandingkan dengan pendidikan konvensional, dalam prosesnya e-learning sebagai media distance learning menciptakan paradigma baru, yakni peran guru yang lebih bersifat "fasilitator" dan siswa sebagai "peserta aktif" dalam proses belajarmengajar. Karena itu, guru dituntut untuk menciptakan teknik mengajar yang baik, menyajikan bahan ajar yang menarik, sementara siswa dituntut untuk aktif berpartisipasi dalam proses belajar.

Dalam kaitannya dengan fungsi media pembelajaran, Nurseto (2011) menekankan beberapa hal yaitu: sebagai alat agar pembelajaran menjadi lebih efektif; 
mempercepat proses belajar; meningkatkan kualitas proses belajar-mengajar; mengkongkretkan yang abstrak sehingga dapat mengurangi terjadinya penyakit verbalisme. Pemanfaatan TIK dalam proses pembelajaran menunjukkan pengaruhnya yang signifikan terhadap peningkatan hasil belajar siswa. Hal ini ditunjukan oleh beberapa hasil penelitian sebagai berikut.

Berdasarkan penelitian yang dilakukan oleh Ernayanti, dkk. (2017), diketahui bahwa terdapat perbedaan kemampuan menyimak antara anak yang diberikan pembelajaran dengan metode bercerita bermediakan audio visual pembelajaran dan anak yang diberikan pembelajaran dengan metode konvensional (ceramah dan tanya jawab). Dengan demikian, metode bercerita bermediakan audio visual pembelajaran berpengaruh terhadap kemampuan menyimak pada anak kelompok B di TK Gugus III Kecamatan Buleleng tahun ajaran 2016/2017.

Penelitian lainnya yang dilakukan oleh Sri Tulasih (2016) menunjukkan bahwa penggunaan media gambar sangat mendukung kegiatan pembelajaran dan menunjang perkembangan bahasa serta perubahan sikap anak TK Sultan Agung Nglanjaran Sardonoharjo Ngaglik Sleman Yogjakarta. Penelitian yang dilakukan Daroah (2013) juga menunjukkan kemampuan bahasa yang dicapai anak didik kelompok RA Perwanida Slawi lebih meningkat di bandingkan dengan sebelumnya di mana perkembangan bahasa anak hanya mencapai 50\%. Namun setelah dilakukan praktik penelitian tindakan kelas melalui metode bercerita dengan menggunakan media audio visual, pada siklus pertama mengalami peningkatan mencapai $75 \%$. Oleh karena itu, dilakukan penelitian ulang sehingga pada siklus kedua mengalami peningkatan mencapai $85 \%$, di mana tingkat pencapaian tersebut sudah memenuhi target penelitian yaitu 85\%. Guru pun merasa lebih mudah dalam menyampaikan metode bercerita, dan memberikan pembelajaran yang menyenangkan.

Hasil penelitian lainnya yang dilakukan oleh Wulandari (2013) menunjukkan bahwa penggunaan media audio visual memiliki pengaruh yang positif dan signifikan terhadap kemampuan berbahasa pada anak usia 4-5 tahun di TK Aisyiyah Ngringo IV Jaten Karanganyar Tahun Pelajaran 2012/ 2013. Peningkatan kemampuan berbahasa anak usia dini dapat dilihat dari nilai rata-rata kemampuan berbahasa anak setelah pembelajaran dengan media audio visual yang mencapai 34,000 , lebih tinggi dibandingkan sebelum pembelajaran yang hanya mencapai 27,000. Hal ini menunjukkan bahwa anak usia dini yang telah diberi pembelajaran dengan media audio visual memiliki kemampuan berbahasa yang lebih baik.

Penelitian ini memilliki beberapa perbedaan dengan penelitian sebelumnya, yang salah satunya adalah bahwa penelitian ini bersifat studi pustaka yang berupaya mengonstruksi berbagai hasil temuan di lapangan mengenai pemanfaatan teknologi informasi yang diterapkan dalam metode bercerita agar menjadi sebuah rumusan yang lebih komprehensif sehingga dapat diterapkan secara umum oleh para guru dan orang tua dalam melaksanakan kegiatan pembelajaran. Di samping itu, penelitian tidak didasarkan pada pengujian suatu hipotesis tertentu, sebagaimana penelitian lainnya, melainkan dibangun atas beberapa persoalan dasar yang selanjutnya digunakan dalam rangka menjawab tujuan penelitian yang kemudian dianalisis dan disajikan secara deskriptif. Hal ini tentunya dengan mempertimbangkan bahwa penelitian ini sesuai dengan paradigma penelitian jenis kualitatif pada umumnya.

\section{HASIL DAN PEMBAHASAN}

\section{Metode Penyampaian Cerita}

Sebagaimana diketahui, cerita adalah rangkaian peristiwa yang disampaikan, baik berasal dari kejadian nyata (non fiksi) maupun tidak nyata (fiksi). Kata dongeng berarti cerita rekaan/tidak nyata/fiksi, seperti: fabel (binatang dan benda mati), sage (cerita petualangan), hikayat (cerita rakyat), legenda (asal usul), mitos (dewa-dewi, peri, roh halus), epos (cerita besar; Mahabharata, 
Ramayana, saur sepuh, tutur tinular). Jadi, dongeng adalah cerita, namun cerita belum tentu dongeng. Metode bercerita berarti penyampaian cerita dengan cara bertutur. Yang membedakan antara bercerita dengan metode penyampaian cerita lain adalah lebih menonjol aspek teknis penceritaannya. Sebagaimana phantomim yang menyampaikan cerita dengan lebih menonjolkan aspek gerak dan mimik, operet yang lebih menonjolkan musik dan nyanyian, puisi dan deklamasi yang lebih menonjolkan syair, sandiwara yang lebih menonjol pada permainan peran oleh para pelakunya, atau monolog (teater tunggal) yang mengoptimalkan semuanya. Metode bercerita lebih menonjolkan penuturan lisan materi cerita dibandingkan aspek teknis yang lainnya.

Menurut para ahli pendidikan, bercerita kepada anak-anak memiliki beberapa fungsi yang amat penting, yaitu: (1) membangun kedekatan emosional antara pendidik dengan anak; (2) media penyampai pesan/nilai moral dan agama yang efektif; (3) pendidikan imajinasi/fantasi; (4) menyalurkan dan mengembangkan emosi; (5) membantu proses peniruan perbuatan baik tokoh dalam cerita; (6) memberikan dan memperkaya pengalaman batin; (7) sarana hiburan dan penarik perhatian; (8) menggugah minat baca; dan (9) sarana membangun watak mulia. Hal lain mengenai manfaat metode bercerita terhadap pendidikan anak sebagaimana diungkapkan oleh Collins (1999) adalah bahwa metode bercerita ternyata akan terkait dengan kemampuan anak (untuk menulis, membaca, berbicara, dan menggambar), perkembangan afeksi anak, penanaman nilai dalam diri anak, dan menjadi bagian dari upaya pemertahanan budaya.

Penelitian yang dilakukan oleh Prins, et.al (2017) menunjukkan bahwa metode bercerita dapat mendorong pemahaman anak terhadap pendidikan sains.

Selain itu, Subyantoro (2008) mengemukakan bahwa bercerita yang baik dapat mengaktifkan otak emosional anak dan mengondisikan saraf otak bekerja secara rileks dan mediatif. Hal tersebut dinilai sebagai kekuatan penting dalam metode bercerita dalam meningkatkan kecerdasan emosional anak. Saat anak mendengarkan cerita, saraf otak mereka bekerja dalam gelombang alpha, sehingga saraf otak berada dalam kondisi rileks dan terjadi hubungan antar serabut sel secara bergantian.

\section{Pemilihan Cerita dan Persiapan}

Sebelum bercerita, pendidik harus memahami terlebih dahulu tentang cerita apa yang hendak disampaikannya, yang tentu saja harus disesuaikan dengan karakteristik anakanak usia dini. Agar dapat bercerita dengan tepat, pendidik harus mempertimbangkan materi ceritanya. Pemilihan cerita antara lain ditentukan oleh beberapa hal.

Pertama, pemilihan tema dan judul yang tepat. Bagaimana cara memilih tema cerita yang tepat berdasarkan usia anak? Seorang anak hidup dalam alam khayal. Anak-anak menyukai hal-hal yang fantastis, aneh, yang membuat imajinasinya "menari-nari". Bagi anak-anak, hal-hal yang menarik itu berbeda pada setiap tingkat usia, misalnya pada usia 4 tahun, anak menyukai dongeng fabel dan horor, seperti Si Wortel, Tomat yang Hebat, Anak Ayam yang Manja, Kambing Gunung dan Kambing Gibas, Anak Nakal Tersesat di Hutan Rimba, Cerita Nenek Sihir, Orang Jahat, Raksasa yang Menyeramkan, dan sebagainya. Sedangkan pada usia 4-8 tahun, anak-anak menyukai dongeng jenaka, tokoh pahlawan/hero dan kisah tentang kecerdikan, seperti Perjalanan ke Planet Biru, Robot Pintar, Anak yang Rakus, dan sebagainya. Kemudian pada usia 8-12 tahun, anak-anak menyukai dongeng petualangan fantastis rasional (sage), seperti Persahabatan si Pintar dan si Pikun, Kami Juara Menyanyi, dan sebagainya.

Kedua, waktu penyajian dengan mempertimbangkan daya pikir, kemampuan bahasa, rentang konsentrasi, dan daya tangkap anak. Oleh karena itu, perlu diperhatikan hal-hal berikut ini: (a) sampai usia 4 tahun, durasi waktu cerita hingga 7 menit; (b) usia 4-8 tahun, durasi waktu cerita hingga 10 -15 menit; dan (c) usia 8-12 tahun, durasi waktu cerita hingga 25 menit. Namun tidak menutup kemungkinan bahwa durasi waktu bercerita menjadi lebih panjang apabila tingkat 
konsentrasi dan daya tangkap anak dirangsang oleh penampilan pencerita yang sangat baik, atraktif, komunikatif, dan humoris.

Ketiga, suasana (situasi dan kondisi). Suasana disesuaikan dengan acara/peristiwa yang sedang atau akan berlangsung, seperti acara kegiatan keagamaan, hari besar nasional, ulang tahun, pisah sambut anak didik, peluncuran produk, pengenalan profesi, program sosial, dan lain-lain. Suasana yang berbeda akan berbeda juga jenis dan materi ceritanya. Pendidik dituntut untuk memperkaya diri dengan materi cerita yang disesuaikan dengan suasana. Jadi, akan ada keselarasan antara materi cerita dengan acara yang diselenggarakan, bukan satu atau beberapa cerita untuk segala suasana.

Dengan atau tanpa alat peraga, jalan cerita yang disampaikan guru pada anak harus memiliki beberapa kriteria. Kriteria cerita yang baik serta cocok dengan kehidupan anak adalah sebagai berikut. Pertama, cerita harus menarik dan memikat perhatian guru sendiri sehingga guru bersungguh-sungguh dalam bercerita. Kedua, cerita harus sesuai dengan kepribadian, gaya, dan bakat anak agar mereka lebih tertarik dan lebih terlibat dalam kegiatan bercerita. Ketiga, cerita disesuaikan tingkat usia dan kemampuan anak mencerna isinya (Moeslichatoen, 2004:166-167 dalam Saputra, dkk. 2016).

\section{Hal-hal yang Perlu Diperhatikan Saat Bercerita}

Bakat seseorang dalam berbicara di depan banyak orang memang sangat berpengaruh dalam menyajikan cerita. Ada orang yang secara alami sangat memikat perhatian orang lain dalam hal berbicara. Untuk orang semacam ini, menyampaikan cerita bukan hal yang susah. Namun, bukan berarti orang yang tidak memunyai bakat alam semacam itu tidak dapat menyampaikan cerita dengan baik. Dengan belajar dan berlatih, orang yang tidak berbakat seperti itu dapat juga menyampaikan cerita dengan baik. Beberapa hal yang perlu diperhatikan saat bercerita adalah sebagai berikut.

Pertama, penampilan. Pengertian penampilan meliputi banyak hal. Penampilan tidak hanya masalah busana, tetapi juga kebersihan, kerapian, ekspresi suasana hati, dan sikap. Dalam hal busana, seorang pengajar harus mengenakan pakaian yang sopan dan fungsional. Riasan wajah tidak perlu mencolok seperti hendak menghadiri pesta. Demikian juga perhiasan. Pengajar tidak perlu memakai semua perhiasan yang dimiliki sehingga pengajar malah terlihat seperti boneka pajangan. Yang terpenting adalah bahwa seorang guru yang berpenampilan "apik" akan lebih diperhatikan daripada yang rambutnya tidak rapi dan bermuka masam.

Kedua, gaya bicara. Meski telah disampaikan di atas bahwa media visual terbukti lebih efektif jika dibandingkan dengan media audio, tetapi suara guru tetap merupakan alat yang sangat penting. Sebaik apa pun alat bantu yang digunakan, penjelasan dari pembicara tetap dibutuhkan. Poin Ketiga, Keempat, dan Kelima berikut ini terkait dengan aspek gaya bicara yang perlu diperhatikan.

Ketiga, audibilitas. Suara harus dapat didengar oleh anak yang duduk paling jauh dari pengajar. Suara yang cukup keras akan mencegah anak-anak melakukan kegiatan sendiri atau mengganggu kawan yang lain.

Keempat, nada. Nada suara guru dapat menarik perhatian dan keingintahuan anak. Nada suara yang datar tidak akan menarik perhatian pendengar, baik dewasa maupun anak-anak. Akan jauh lebih baik bila guru dapat menggunakan variasi nada suara sesuai dengan suasana atau kejadian yang sedang diceritakan, misalnya berbisik, marah, berseru, sedih, menyesal, membentak, dan lain sebagainya. Namun perlu diingat, suara harus tetap terdengar oleh anak-anak.

Kelima, kecepatan. Kecepatan bicara juga memengaruhi pemahaman anak terhadap cerita yang sedang disampaikan. Cerita yang disampaikan dengan cepat akan susah dipahami, sebaliknya cerita yang bertempo lambat akan membosankan dan menghabiskan waktu.

Keenam, bahasa tubuh. Komunikasi tidak hanya melibatkan bahasa verbal (yang terucap), tetapi juga yang nonverbal (yang tak terucap), yang sering disebut bahasa tubuh. 
Bahasa tubuh adalah istilah dalam bidang psikologi yang menunjuk pada gerakan atau tindakan yang merefleksikan emosi sehingga dapat dilihat dari luar. Sebagai contoh, orang yang sedang marah tidak perlu mengatakan "saya marah" agar orang lain tahu bahwa ia sedang marah. Sebaliknya bila sedang gembira, ia tidak perlu mengatakan "saya gembira". Ada kalanya bahasa tubuh ini sesuai dengan apa yang diucapkan, akan tetapi ada kalanya pula bertentangan dengan apa yang diucapkan. Karena bahasa tubuh memiliki andil yang cukup besar dalam penyampaian dan penerimaan suatu berita. Sebaiknya guru belajar menggunakan bahasa tubuh dengan efektif.

Beberapa hal yang terkait dengan bahasa tubuh adalah sebagai berikut.

Pertama, senyum. Senyuman akan membuat suasana menjadi hangat dan menyenangkan. Namun, orang lain akan melihat mana senyum yang keluar karena memang sedang bersuka cita dan mana senyum karena terpaksa.

Kedua, mimik. Mimik atau rona wajah akan ikut memengaruhi suasana kelas. Mimik wajah guru akan memengaruhi suasana hati anak-anak juga. Wajah yang cemberut pasti akan mengurangi antusiasme anak-anak dalam mendengarkan cerita. Selain itu, guru yang berpengalaman dapat menggunakan ekspresi wajah untuk menarik perhatian anakanak, misalnya wajah kesakitan, ketakutan, menggigil, dan sebagainya.

Ketiga, kontak mata. Kontak mata merupakan satu hal yang penting dalam komunikasi. Kontak mata merupakan salah satu bentuk perhatian. Kita tentu tidak akan senang bila orang yang sedang berbicara dengan kita tidak pernah atau sangat jarang menatap mata kita. Selain itu, kontak mata juga dapat membantu guru menguasai suasana kelas.

Keempat, gerakan tangan. Penggunaan gerakan tangan dilakukan untuk menunjang cerita. Usahakan untuk tidak menggunakan gerakan yang tidak perlu. Berhati-hatilah dengan gerakan tangan yang mempunyai konotasi negatif.

Kelima, posisi berdiri/duduk. Pilih posisi berdiri/duduk yang tepat agar semua anak masih dapat melihat. Perlu dihindari sikap yang tidak baik dalam duduk atau berdiri (baik dan buruk bergantung pada budaya). Di Indonesia, duduk di meja atau meletakkan kaki di atas kursi dianggap tidak sopan. Namun, hal ini masih bisa dilakukan jika dimaksudkan sebagai contoh atau adegan.

Keenam, kebiasaan bawah sadar. Setiap orang memiliki kebiasaan yang kurang disadari ketika berbicara, seperti misalnya memasukkan tangan ke kantong, bertolak pinggang, atau memegang-megang benda tertentu. Bila kebiasaan semacam ini terlalu sering muncul, pengajaran tentu akan terganggu. Oleh karena itu, sang guru harus berlatih mengurangi kebiasaan bawah sadar ini.

\section{Memanfaatkan TIK dalam Penceritaan}

Dalam menyusun sebuah program pembelajaran berbasis teknologi informasi dan komunikasi, perlu diperhatikan berbagai hal, seperti misalnya mengenai daya pikat. Contohnya adalah penggunaan metode bercerita yang memanfaatkan teknologi informasi dan komunikasi. Sekurangnya terdapat dua aspek yang dapat dipenuhi oleh TIK dalam mendukung metode bercerita ini agar dapat memberikan daya pikat kepada anak-anak didik, sehingga harapannya adalah bahwa mereka dapat menyerap nilai-nilai di dalam cerita dengan baik.

Nurseto (2011) mengungkapkan bahwa dalam melakukan perencanaan pembuatan media meliputi: identifikasi kebutuhan dan karakteristik siswa; perumusan tujuan; memilih, merubah, dan merancang media pembelajaran; perumusan materi; pelibatan siswa; dan evaluasi (Evaluation). Selanjutnya, dalam mengembangkan media pembelajaran perlu diperhatikan prinsip VISUALS, yang dapat digambarkan sebagai singkatan dari kata-kata: Visible: mudah dilihat, Interesting: menarik, Simple: sederhana, Useful: isinya berguna/bermanfaat, Accurate: benar (dapat dipertanggung jawabkan), Legitimate: masuk akal/sah, Structured: terstruktur/tersusun dengan baik. Hal ini ditegaskan oleh Husain (2014) yang mengungkapkan bahwa pemanfaatan teknologi informasi dan komunikasi dalam pembelajaran dilakukan 
dalam rangka meningkatkan efektifitas dalam pelaksanaan proses pembelajaran yang pada akhirnya diharapkan dapat meningkatkan hasil belajar siswa serta mutu individu para peserta didik dalam hal penggunaan teknologi secara lebih tepat dan bermanfaat.

Yuksel, et.al (2011) melalui penelitian yang dilakukannya terhadap pendidik dan pelajar di beberapa negara yang berbeda mengenai persepsi mereka tentang penggunaan teknologi dalam kegiatan bercerita menunjukkan bahwa teknologi memberikan manfaat sekaligus tantangan bagi para pendidik seperti diperlukannya infrastruktur dan sumber daya manusia yang memadai guna menunjang pembelajaran di lembaga pendidikan tersebut.

\section{Efek Visual}

Saat menerapkan metode bercerita ini, kita dapat melengkapinya dengan efek visual yang tujuannya membangun suasana, dan memberikan daya pikat. Namun perlu diperhatikan di sini bahwa efek visual yang ditampilkan haruslah berkaitan dengan tema dan cerita yang disampaikan sehingga anak tidak mengalami kebingungan dalam memahami cerita yang disebabkan oleh efek visual yang tidak tepat atau tidak sesuai. Dalam mengomunikasikan secara visual, pesan bisa dihadirkan atau diekspresikan dalam bentuk gambar dua dimensi atau lebih, termasuk di dalamnya adalah tanda, tipografi, sketsa gambar, desain grafis, ilustrasi, desain industri, iklan, animasi, dan berbagai sumber elektronik (Siddiq \& Hamidi, 2015). Hal lainnya yang perlu diperhatikan adalah agar efek visual yang dimunculkan janganlah sampai mendominasi sehingga mengunci daya imajinasi anak dalam pikirannya. Efek visual yang ditampilkan cukup menjadi latar yang menghiasi cerita yang hendak disampaikan kepada anak. Hal ini selaras dengan yang disampaikan oleh Moeslichatoen (2004:157) dalam Amalia (2015) yang mengungkapkan bahwa inti dari metode bercerita adalah memberi pengalaman belajar bagi anak dengan membawakan cerita kepada anak secara lisan sehingga pengalaman belajar sesungguhnya terjadi saat guru dan anak berinteraksi menikmati alur dari cerita.
Di samping itu, pemberian efek visual diharapkan tidak sampai menyimpang dari tujuan utama dalam penggunaan metode bercerita yaitu untuk mengembangkan kemampuan mendengar anak dan memberikan informasi atau menanamkan nilai-nilai sosial, moral, dan keagamaan serta informasi lingkungan fisik (non-manusia, contoh: binatang, peristiwa, tanaman di halaman, sekolah, dan lain sebagainya) dan lingkungan sosial (orang dalam keluarga, sekolah, masyarakat termasuk jasa seseorang).

\section{Efek Audio}

Efek audio tentulah akan menjadi daya tarik yang sangat efektif. Efek suara akan menjadikan cerita yang disampaikan menjadi lebih hidup. Misalnya saja, cerita "Seekor Singa Sang Raja Rimba" yang diiringi dengan efek suara susana hutan akan membuat cerita menjadi terasa lebih hidup dalam pikiran anak. Selain efek audio, cerita juga akan lebih memiliki daya pikat saat disampaikan dengan selingan musik dan lagu. Ketika pencerita menyampaikan cerita tentang kesedihan, iringan musik bernada melankolis tentunya akan membuat syahdu penyimaknya. Begitu pula saat pencerita menceritakan tentang kisah-kisah heroik yang diiringi dengan musik bertempo cepat dan irama yang semangat akan memberikan efek semangat pula pada penyimaknya.

Pada akhirnya, musik dan lagu yang digunakan sebagai latar atau bagian dari cerita akan membantu untuk menyentuh sisi afeksi penyimak sehingga cita rasa dari cerita yang disampaikan akan dapat mengendap lama dalam pikirannya. Penggunaan alat-alat audio visual seperti sound system, microphone, komputer, layar, infokus, dan sebagainya perlu dipersiapkan dengan baik dan diperiksa kembali sebelum menyampaikan cerita. Hal ini bertujuan untuk menghindari terjadinya kesalahan teknis yang justru dapat berdampak pada tidak tersampaikannya cerita dengan baik kepada penyimak. Kendala yang berpotensi untuk terjadi terkait pemanfaatan media pembelajaran dalam bentuk TIK ini sebagaimana yang diungkapkan oleh 
Rahmattullah (2011) utamanya terjadi dalam proses pembelajaran, yakni: (a) kurangnya kompetensi guru dalam merancang dan mengelola penggunaan media dalam kegiatan pembelajaran; dan (b) keterbatasan muatan materi yang tidak sepenuhnya mampu mengakomodir kebutuhan pembelajaran.

\section{Penyimakan dan Ungkapan Ulang Setelah Penceritaan}

Menyimak adalah proses mendengarkan dengan penuh perhatian. Menyimak adalah suatu proses kegiatan mendengarkan lambang-lambang lisan dengan penuh perhatian, pemahaman, apresiasi, serta interpretasi untuk memperoleh informasi, menangkap isi atau pesan serta memahami makna komunikasi yang telah disampaikan oleh sang pembicara melalui ujaran atau bahasa lisan. Menurut Tarigan (2008: 37), tujuan menyimak adalah memperoleh informasi, menangkap isi, serta memahami makna komunikasi yang hendak disampaikan sang pembicara melalui ujaran. Dalam menyimak, terdapat tahapan-tahapan, sebagai berikut.

Pertama, menyimak berkala, yang terjadi pada saat-saat sang anak merasakan keterlibatan langsung dalam pembicaraan mengenai dirinya.

Kedua, menyimak dengan perhatian dangkal karena sering mendapat gangguan dengan adanya selingan-selingan perhatian kepada hal-hal di luar pembicaraan.

Ketiga, setengah menyimak karena terganggu oleh kegiatan menunggu kesempatan untuk mengekspresikan isi hati serta mengutarakan apa yang terpendam dalam hati sang anak.

Keempat, menyimak serapan karena sang anak keasyikan menyerap hal-hal yang kurang penting, hal ini merupakan penjaringan pasif yang sesungguhnya.

Kelima, menyimak sekali-sekali, menyimpan sebentar-sebentar apa yang disimak, perhatian secara saksama berganti dengan keasyikan lain, hanya memperhatikan kata-kata sang pembicara yang menarik hatinya saja.

Keenam, menyimak asosiatif, hanya mengingat pengalaman-pengalaman pribadi secara konstan yang mengakibatkan sang penyimak benar-benar tidak memberikan reaksi terhadap pesan yang disampaikan sang pembicara.

Ketujuh, menyimak dengan reaksi berkala terhadap pembicara dengan komentar ataupun mengajukan pertanyaan.

Kedelapan, menyimak secara saksama, dengan sungguh-sungguh mengikuti jalan pikiran sang pembicara.

Kesembilan, menyimak secara aktif untuk mendapatkan serta menemukan pikiran, pendapat, dan gagasan sang pembicara.

Pengungkapan ulang atau refleksi menjadi salah satu hal yang tidak dapat diremehkan dalam keberhasilan metode bercerita ini. Alterio (2003:14) mengungkapkan bahwa refleksi dapat menggugah imajinasi dan daya berpikir kreatif anak.

\section{Ungkapan Lisan}

Salah satu tujuan bercerita adalah mengukur kemampuan siswa untuk mengungkapkan ide dan apa-apa yang diketahuinya dari cerita melalui kegiatan penyimakan. Pengungkapan bisa dilakukan dengan lisan dan gerakan tubuh serta ekspresi jiwa, yaitu meragakan sambil bercerita, atau dengan gerakan tubuh dan ekspresi jiwa saja, yaitu peragaan tanpa bicara. Ada pula media lainnya seperti membuat tulisan, gambar, musik, patung, dan sebagainya.

Setelah guru selesai bercerita, ia dapat meminta para siswa untuk mengungkapkan kembali apa-apa yang diketahuinya dari cerita dengan menggunakan salah satu metode pengungkapan berikut ini.

Pertama, siswa menjawab pertanyaanpertanyaan yang diajukan kepadanya. Guru mengajukan beberapa pertanyaan kepada siswa mengenai peristiwa dalam cerita, tokohtokohnya, tokoh yang paling disukai dan dibenci, dan meminta mereka mengemukakan sebab-sebabnya. Pertanyaan yang disampaikan hendaknya pertanyaan yang merangsang siswa untuk berpikir.

Kedua, sebagian siswa menjawab pertanyaan yang diajukan siswa lainnya. Guru dapat membagi siswa menjadi dua bagian. Satu kelompok mengajukan pertanyaan dan 
satu kelompok yang lain menjawabnya, dan mengajukan pertanyaan kepada seluruh siswa yang mendapat bagian menjawab. Kemudian guru atau siswa yang bertanya memilih salah seorang untuk menjawabnya. Tidak baik jika hanya meminta seorang siswa saja untuk mempersiapkan jawaban dari pertanyaan yang diajukan seorang siswa lainnya.

Para siswa yang mendapat bagian bertanya harus seluruhnya berpikir mengenai pertanyaan yang akan diajukan dan guru memilih salah seorang untuk mengajukan pertanyaan tersebut kepada seluruh siswa yang mendapat bagian menjawab. Tujuan dari cara ini adalah agar para siswa merasakan atau bisa mengajukan pertanyaan setelah mendengar cerita. Hal ini sebaiknya dilakukan secara bergantian. Kelompok yang sebelumnya bertanya diganti menjadi kelompok yang menjawab atau sebaliknya.

Ketiga, para siswa sebagai pencerita. Guru dapat meminta salah seorang siswa untuk bercerita, seluruhnya atau sebagian saja, lalu dilanjutkan oleh yang lainnya sampai selesai. Hal ini bisa dilakukan langsung setelah guru bercerita atau pada jam yang lain. Akan lebih baik jika siswa terbiasa bercerita sendiri di depan teman-temannya sehingga dapat menimbulkan kebiasaan berbicara di hadapan orang banyak dan menumbuhkan keberanian. Bisa saja siswa yang bercerita melakukan kesalahan ketika bercerita, hal ini akan memancing temantemannya untuk berlomba membetulkan. Namun hal ini kurang baik, karena akan memotong pencerita dan mengacaukan pikirannya. Oleh karena itu, yang lebih baik adalah tidak memotong siswa yang bercerita tetapi menunggu sampai cerita yang disampaikannya selesai.

\section{Pemanfaatan Teknologi dalam Pengungkapan Ulang}

Penggunaan komputer interaktif sebagai variasi pembelajaran akan menjadi menarik bagi para anak didik. Misalnya saja setelah menyimak cerita, mereka kemudian mengerjakan tugas latihan dengan menggunakan komputer yang berisi pertanyaan-pertanyaan yang berkaitan dengan cerita yang telah disampaikan sebelumnya.

Contoh lainnya adalah ketika anak selesai mendengarkan cerita, mereka dapat diminta untuk membuat desain gambar, animasi, powerpoint, dan lain sebagainya dengan memanfaatkan teknologi yang ada. Hal ini tentulah menarik dan memberikan tantangan tersendiri bagi para anak didik, di samping untuk melatih mereka agar lebih menguasai teknologi informasi dan komunikasi dengan lebih baik lagi.

\section{SIMPULAN DAN SARAN}

Berdasarkan hasil uraian dalam pembahasan, dapat diperoleh beberapa simpulan guna menjawab pertanyaan penelitian ini.

Cerita atau dongeng semestinya berada pada posisi pertama dalam mendidik etika kepada anak. Dalam cerita terdapat ide, tujuan, imajinasi, bahasa, dan gaya bahasa. Unsur-unsur tersebut berpengaruh dalam pembentukan pribadi anak. Agar cerita dapat disampaikan dan diserap oleh anak didik secara optimal, guru dapat menggunakan TIK. Namun demikian, perlu dipahami bahwa TIK digunakan sebagai pendukung metode bercerita sehingga para guru tetap perlu mengasah kemampuannya dalam menyampaikan cerita secara menarik kepada peserta didik.

Pelajaran bahasa mengambil peran pada bagian cerita sastra yang baik bagi anak-anak. Melalui penyimakan cerita yang disajikan, selain keterampilan menyimak anak-anak akan meningkat, mereka juga akan menyerap nilai-nilai dalam cerita tersebut. TIK dapat digunakan untuk memperpanjang daya perhatian anak dalam menyimak cerita. Akan tetapi, perlu diperhatikan guru agar tidak menggunakan visualisasi dan audio yang berlebihan sehingga kemudian justru akan membatasi daya imajinasi anak saat mendengarkan cerita.

Dalam cerita, ada beberapa pokok yang masing-masing akan saling berkaitan, yaitu pengarang, karangan, pencerita, penceritaan, penyimak dan penyimakan. Keenam pokok tersebut perlu diperhatikan agar metode 
bercerita dan pemanfaatan TIK-nya dapat efektif.

Penyimakan dan ungkapan ulang setelah penceritaan merupakan hal yang sangat penting untuk dilakukan dalam kegiatan bercerita. Salah satu tujuannya adalah untuk mengukur kemampuan siswa dalam mengungkapkan ide dan hal-hal yang diketahuinya dari cerita melalui kegiatan penyimakan.

Selanjutnya, melalui hasil penelitian ini, dapat diberikan saran kepada para guru dan lembaga pendidikan serta orang tua agar dapat mempelajari bagaimana merancang dan memanfaatkan TIK dengan optimal sehingga dapat meningkatkan kualitas hasil pembelajaran. Perlu diketahui bahwa manfaat TIK dalam menunjang penyampaian cerita sekurangnya terdapat pada dua aspek yaitu efek visual dan audio.

Berdasarkan kajian ini pula, disarankan kepada guru dan lembaga pendidikan serta orang tua bahwa pada saat pengungkapan ulang, media interaktif dapat menjadi salah satu variasi belajar yang mendukung metode bercerita ini sehingga guru maupun orang tua yang ingin menggunakan metode bercerita dengan memanfaatkan teknologi informasi dan komunikasi diharapkan dapat memiliki kemampuan dalam merancang pembelajaran berbasis TIK ini.

\section{DAFTAR PUSTAKA}

\section{Buku}

Alterio, M., McDrury, J. (2003). Learning Through Storytelling in Higher Education. London: Routledge, https://doi.org/10.4324/ 9780203416655

Kridalaksana, Harimurti. (2001). Kamus Linguistik. Jakarta: Gramedia Pustaka Utama.

Majid, Abdul Aziz Abdul. (2001). Mendidik dengan Cerita. Bandung: Remaja Rosdakarya.

Moeslichatoen, R. (2004). Metode Pengajaran Di Taman Kanak - Kanak. Jakarta: PT Asdi Mahasatya.

Tarigan, H. Guntur. (1982). Menulis Sebagai Suatu Keterampilan Berbahasa. Bandung: Angkasa.

\section{Jurnal/Prosiding}

Amalia, T.Z. (2015). Bercerita sebagai Metode Mengajar bagi Guru Raudlatul Athfal dalam Mengembangkan Kemampuan Dasar Bahasa Anak Usia Dini di Desa Ngembalrejo Bae, Kudus. ThufuLA: Jurnal Inovasi Pendidikan Guru Raudhatul Athfal, 3(2), pp.334-353. http:/ /journal.stainkudus.ac.id/index.php/thufula/ article/download/4736/3062.

Collins, F. (1999). The Use of Traditional Storytelling in Education to the Learning of Literacy Skills. Early Child Development and Care, 152(1), pp.77-108. https://doi.org/ 10.1080/0300443991520106

Ernayanti, Luh Wiwin, et.al. (2017). Pengaruh Metode Bercerita Bermediakan Audio Visual Pembelajaran Terhadap Kemampuan Menyimak Anak Gugus III Kecamatan Buleleng. Journal Pendidikan Anak Usia Dini Universitas Pendidikan Ganesha Jurusan Pendidikan Guru Pendidikan Anak Usia Dini, Volume 5. No. 1. https://ejournal.undiksha. ac.id/index.php/JJPAUD/article/viewFile/ 11534/7385

Gultom, Nurjannah. (2017). Pemanfaatan Teks Feature Perjalanan sebagai Media dalam Pembelajaran Menulis Karangan Naratif. https://media.neliti.com/media/publications/ 55469-ID-pemanfaatan-teks-featureperjalanan-seba.pdf

Husain, C. (2014). Pemanfaatan Teknologi Informasi dan Komunikasi dalam Pembelajaran di SMA Muhammadiyah Tarakan. Jurnal Kebijakan dan Pengembangan Pendidikan, 2(2). http:// ejournal.umm.ac.id/index.php/jmkpp/article/ view/1917

Haryoko, S. (2009). Efektivitas Pemanfaatan Media Audio-visual sebagai Alternatif Optimalisasi Model Pembelajaran. Jurnal Edukasi Elektro, 5(1). https://journal.uny.ac.id/ index.php/jee/index

Nurseto, T. (2011). Membuat media pembelajaran yang menarik. Jurnal Ekonomi dan Pendidikan, 8 (1). https://journal.uny.ac.id/ index.php/jep/article/view/706

Prins R, Avraamidou L, Goedhart M. (2017). Tell Me a Story: The Use of Narrative as a Learning Tool for Natural Selection. Educational Media International. Jan 2; 54(1):20-33. https:// 
doi.org/10.1080/09523987.2017.1324361

Rahmatullah, M. (2011). Pengaruh Pemanfaatan Media Pembelajaran Film Animasi terhadap Hasil Belajar. Jurnal Penelitian Pendidikan, 12 (1), pp.178-186. http://jurnal.upi.edu/file/17Muhammad_Rahmattullah.pdf

Siddiq, M., \& Hamidi, J. (2015). Komunikasi Visual Iklan Layanan Masyarakat Dana Bos sebagai Bahan Belajar. Jurnal Teknodik, 19 (2), 147160. DOI: http://dx.doi.org/10.32550/ teknodik.v19i2.156

Saputra, W.N.E. and Setianingrum, I. (2016). Perkembangan Motorik Halus Anak Usia 3-4 Tahun di Kelompok Bermain Cendekia Kids School Madiun dan Implikasinya pada Layanan Konseling. Jurnal CARE (Children Advisory Research and Education), 3(2), pp.111. http://e-journal.unipma.ac.id/index.php/ JPAUD/article/download/536/480

Subyantoro, S. (2018). Pengembangan Perangkat Bercerita Untuk Meningkatkan Kecerdasan Emosional. Jurnal Teknodik, 12 (1), pp.055063. https://jurnalteknodik.kemdikbud.go.id/ index.php/jurnalteknodik/article/view/420

Trisanto, T., Syam, C. and Seli, S. Gaya Bahasa dalam Kumpulan Cerpen Kacapiring Karya Danarto (sebuah Kajian Stilistika). Jurnal Pendidikan dan Pembelajaran, 2(9). http:// jurnal.untan.ac.id/index.php/jpdpb/article/view/ 3238

Yuksel, P., Robin, B. and McNeil, S. (2011). March. Educational Uses of Digital Storytelling All Around the World. Society for Information Technology \& Teacher Education International Conference (pp. 1264-1271). Association for the Advancement of Computing in Education (AACE). https://www.learntechlib.org/p/36461/

\section{Disertasi/Thesis/Skripsi}

Daroah. (2013). Meningkatan Kemampuan Bahasa Melalui Metode Bercerita dengan Media Audio Visual di Kelompok B1 RA Perwanida 02 Slawi. (Skripsi). Semarang: Pendidikan Guru Pendidikan Anak Usia Dini Fakultas IImu Pendidikan Universitas Negeri Semarang. https://lib.unnes.ac.id/18889/1/ 1601910029.pdf

Sri Tulasih. (2016). Penggunaan Metode Bercerita dengan Media Gambar dalam Meningkatkan Motivasi Kemampuan Berbahasa Anak Usia Dini Kelompok B di TK Sultan Agung Sadonoharjo Ngaglik Sleman Yogjakarta Tahun Ajaran 2015/2016.(Tesis). Yogjakarta: Pascasarjana UIN Sunan Kalijaga. http:// digilib.uin-suka.ac.id/22669/1/14204 31013_bab-i_iv-atau-v_daftar-pustaka.pdf

Suryani, Y. (2017). Implementasi Model Pembelajaran Example Non Example Sebagai Upaya Peningkatan Kemampuan Berpikir Kritis dan Kemampuan Menyusun Teks Tanggapan Kritis pada Siswa Kelas IX SMP Negeri 5 Subang Tahun Pelajaran 2016/2017. (Disertasi). UNPAS.

Wulandari, Depi. (2013). Pengaruh Penggunaan Media Audio Visual terhadap Kemampuan Berbahasa Anak Usia 4-5 Tahun di TK Aisyiyah Ngringo IV Jaten Karanganyar Tahun Pelajaran 2012/2013.(Skripsi). Pendidikan Anak Usia Dini. Surakarta: Fakultas Keguruan dan IImu Pendidikan, Universitas Muhammadiyah Surakarta. http://eprints. ums.ac.id/24876/11/NASKAH_PUBLIKASI. pdf. 
